\title{
“CZŁOWIEKA (TERAZ), O MUZO, WYPOWIEDZ" (“OF MAN [NOW], MUSE, SING"1. AN ATTEMPT TO RECOGNIZE THE ARTISTIC SHAPE OF NORWID'S DRAMA KLEOPATRA I CEZAR (CLEOPATRA AND CAESAR)
}

The reading of the historical tragedy Cleopatra and Caesar leaves one with a vague impression that this drama has features of some turning, liminal point. As Sławińska wrote, it is "a poetic, theatrical, historical, philosophical and even moral summa"; 2 after all at the time of its writing Norwid was accomplishing a grand summa poeticum in his Vade-mecum. However, Cleopatra and Caesar is probably not the peak of Norwid's artistic skills as a playwright. It is different than his earlier dramas such as Krakus or Wanda. At the same time, in Norwid's "beloved tragedy" we can see the return to the earlier style (number of protagonists, group scenes, choirs, large open stage), but also the forerunner of new trends, seen mostly in the stress on the personal, spiritual aspects of the lives of key protagonists, and the focus on individual gestures and props performed in lyrical mode. This clearly sensed breakthrough character is a bit surprising, because, after all, it was Norwid's late drama, and at times his earlier plays, such as Aktor (An Actor) seem to be structurally closer to Pierścień wielkiej damy

\footnotetext{
1 Cyprian Norwid, Milczenie. All the quotes of Norwid come from Cyprian Norwid, Pisma wszystkie, ed. by J. W. Gomulicki, t. I-XI, Warszawa 1971-1976. Roman numbers for volumes, Arabic for pages. Here: Tu: VI, 245. "Of Man, now, the Muse, sing”.

2 Irena Sławińska, Reżyserska ręka Norwida, Kraków 1971, . 251.
} 
(The Ring of a Grand Lady) and Miłość czysta u kapieli morskich (Pure Love at Sea Bathing) than Cleopatra and Caesar. However, it does not happen because of the common comic character or the contemporary setting. Maybe this is the result of the chronological placing of the plot of the drama-a history of powerful empires and cultures in times of crisis.

Joanna Zach-Błońska observed-in a manner similar to the majority of researchers - the compositional and stylistic diversity of Norwid's dramas: "almost all of them are separate experiments, subsequent stages on the road to the form sufficiently capacious."3 It seems that the uniqueness of Cleopatra is grounded in the strong authorial search (more prominent here than elsewhere) for full, absolute form, both in terms of themes and of the poetic shape of this drama. On the other hand, the experimental character of this tragedy includes a certain type of permanent repeatability and immutability: metaphors, key motives, linguistic and structural devices common both to drama and poetry. These issues will be dealt with in the further, analytical part of this paper.

Undoubtedly, Cleopatra and Caesar is unique in Norwid's oeuvre in its loquaciousness (with the simultaneous use of dramatic silences), its multiplicity of themes, and the construction of many layers of meanings, so characteristic for Norwid, which here achieve an unprecedented scale. The level of complexity of the drama's themes is so high that Sławińska, dealing with issues of the proper understanding of a historical tragedy, asked:

In what sense historical? Romantic? Costume? Or maybe 'scientific', archaeological, born from inspiration of the Parnassus of this period? [...]

Or maybe it is a historical and philosophical tragedy which tests some laws universal in history? [...] Maybe general themes: questions about the conditions of a vibrant cultures and conditions of the downfall

\footnotetext{
3 Joanna Zach-Błońska, Monolog różnogłosy, Kraków 1993, 99-100.
} 
of a state ("perversion of a nation") are more important here than the case of one definite historical period. ${ }^{4}$

Questions about the directions of interpretations of this drama could be multiplied. The existing research on this text has been centred around historical and philosophical contexts; the history of nations at the moment of their fall. Less attention has been drawn, however, to the concrete protagonist of the drama. It is true that "the vision of human personality in history" has been noted, its tragic dimension, but more as a realization of the model of an individual, ${ }^{5}$ “jakoby stadiów idealnych" ("as if ideal stages”) ${ }^{6}$ (Pierścień Wielkiej Damy, V, 188), the presence of which in Polish literature was so fiercely attacked by Norwid himself. Less attention has been paid to deeply anthropological features, connected with the understanding of the fullness of humanity: man and woman "istotnych i całych" ("crucial and whole") (Pierścień Wielkiej Damy, V, 188), discernible mostly in these parts of the drama when lyricism is the constitutive part of the language.

A certain type of semantic muss of this text and the lack of an ending condition the research method of the loose selection of themes and research material, and as a result of it-of selective analysis and presentation of conclusions. There is no doubt whatsoever about the multilayered character and semantic complexity of Cleopatra and Caesar. It seems, however, that at the highest level of all semantic intricacies and complexities there is always an individual man and his lot submerged in the history of the world.

When Cleopatra appears on stage she is perceived first of all as a restless, pondering woman, uttering clipped thoughts into space, as if she was looking at this place for the first time and trying to establish what has changed and what has not changed, and what has really happened:

4 Irena Sławińska, Reżyserska ręka Norwida, op. cit., 252.

5 Sławomir Świontek, Norwidowski teatr świata, Łódź, 1983, 137.

6 C.f., ibidem. 
Pałac ten nie pałacem już, ale namiotem:

Monarchini królową nie jest...

Przechadza się i zatrzymuje przed sfinksem.

sfinksem, ...Sfinks jest

On, który się uśmiecha w swoje własne usta

I powstrzymuje wyraz twarzy...

Dotyka palcem głowy Sfinksa.

...lecz we wnętrzu

On sam tylko jest szczerym - kamieniem: nic więcej!...

Potrąca krótką włócznią w tarczę.

Słudzy nasi, czy jeszcze są sługami?!! - pytam.

Cleopatra realizes that the place she is now has become something fickle, temporary, transitory, provisional. The first sentence she speaks also makes the space undergo some strange change. Stage directions indicate that this is some room in the palace, that is that it is a place which is built-in, monumental, while the words "The palace is not a palace but a tent" annul space limitations, and allow for the exit from a palace to an open sphere. This is performed thanks to the powers of expression which words have: Cleopatra, in a way, constructs this space, simultaneously creating from it artistic pictures of her own experiences. Therefore, we are entitled to speak about the lyricism of the space in Norwid's drama, or at least of its strong subjectivism. ${ }^{8}$

7 "This palace is no longer a palace, but a tent./The monarch is not a queen.../ She walks around and stops in front of the sphinx./...A sphinx is a sphinx./He who smiles into his own mouth./And keeps his face straight.../Touches the head of the sphinx with his finger./...but inside/Only he is a real - stone: nothing more!.../ Nudges a short spear against a shield. Our servants, are they still servants?!! - I ask.”

${ }^{8}$ It is not only subjectivism which is to transform from the enclosed space into the space of history and culture, which was the point of Elżbieta Żwirkowska, but about a smooth connection of the surround world with the infernal spiritual sphere of the female protagonist. See Elżbieta Żwirkowska, Tragedia kultur. Studium o tragedii historycznej C. K. Norwida, „Kleopatra i Cezar”, Lublin 1991, 106. 
A metaphor connecting an Alexandrine palace with a tent shows not so much the antinomy which the Egyptian culture creates ${ }^{9}$ but a rift in the protagonist. Cleopatra loses the sense of existential and social stability. She loses her identity, something which has defined her. "Monarchini królową nie jest". (“The monarch is not a queen”). There appears a hole in her mind, which will be slowly filled with new perception of herself. At this moment, one of Norwid's poem comes to mind, in which there is a tent "dom [...] ruchomy / $\mathrm{z}$ wielbłądziej skóry" («a mobile home/of camel»s skin») and a pilgrim whose soul heaven "porywa jak piramidę!" ("picks up as a pyramid"), ${ }^{10}$ but Cleopatra will not be picked up to heaven, for her

[...] zamki monarchów, i grody,

I domostwa są tylko zajezdnymi wroty,

Groby zaś mieszkaniami istotnymi. [...]

$$
(\mathrm{V}, 24)^{11}
$$

This is only partial recognition of one's being. Norwid's poem has been quoted here with a purpose: it stresses that the look was directed not upwards but downwards, and it shows the difference between these two looks. Tombs, mummies and Sphinxes are constant points of reference in Cleopatra life, for her only the space of the necropolis is real and constant. The frequency with which, in the memory of readers, other poems of Norwid's are recalled allows us to estimate the type of thoughts and pictures his mind was preoccupied with-in this case connected with the culture and landscapes of Egypt. We have the same type of imagery in all his writings, as if it was just one canon.

9 Żwirkowska wrote that "the juxtaposition of the heavy lump of the Egyptian palace in Alexandria with the function of a tent-is more than a metaphor, it is naming of antinomy, which the Egyptian culture creates in the concrete political situation". See Elżbieta Żwirkowska, op. cit., 107.

10 Cyprian Norwid, Pielgrzym, all quotations from Vade-mecum come from this edition Cyprian Norwid, Vade-mecum, ed. by Józef Fert, Wrocław 1999. Hereafter (VM) and the pages' number, here 33-34.

11 “[...] monarchs' castles and towns./And homes are only passing gates,/while graves the real homesteads." 
In the fragment dealt with here only the Sphinx remains the Sphinx. And again, it seems worthwhile to recall two poems bearing this title and to quote a fragment from one of them, where to a truly Sphinxlike question about a man the protagonist answers with a famous gnomic formula:

'Man?... he's an ignorant callow Priest. ${ }^{12}$

These words, although at first glance they may seem to be unconnected with the drama, correspond well with the speech of Cleopatra. She ceases to understand and recognize the surrounding world, as everything she used to hold dear has lost value, and therefore she has to (and such is in reality the sense of her words) ask about herself anew. And this question-about man's definition-becomes the key question of the drama. The semantic aspects of ignorance and callowness on which Norwid's definition is based as it appears in Vade-mecum, in a sense, are characteristic of Cleopatra's state of awareness: her own dignity as well as ignorance and immaturity are converted into cognition and understanding.

The recognition of the world by Cleopatra is possible thanks to the fact that she not only looks down, but that she also looks around. She possesses the feature of incisive observation and analysis of what surrounds her, other people and herself. She can look above what can be seen in the foreground, she looks further, she can, as Norwid defined it; "z-dłużyć swój wzrok poza oko" ("elongate her sight beyond the eye”) (Pierścień Wielkiej Damy, V, 225).

Let us return now to the Sphinx's symbolism. It is of a dual nature. The Sphinx (according to mythology) is a patron of great questions asked in the drama, and simultaneously in Egypt it is a symbol of power, so when Cleopatra says that "inside/ [...] he is-just a stone , nothing more", in this way she challenges her primary role. In the Egyptian culture Sphinx has the shape of a protstrate lion with a man's head. It worth remembering that in the telling sixth scene

12 C.K. Norwid, "The Sphinx" in Selected Poems, transl. by Adam Czerniawski, Anvil Press Poetry, London, 2004, 69. 
Cleopatra kneels in front of Caesar on an outstretched lion's hide, and in this way two unusual personalities meet; personalities who are also remarkable symbols. We will return to these reflections later.

The quoted fragment has this quality that in fact it cannot be read without equal treatment of stage directions (and the other way round, stage directions will be of little help without a poetic monologue). Let us recall: Cleopatra "walks around and stops in front of the Sphinx", "touches the Sphinx's head with a finger", "nudges a short spear against a shield". Without this knowledge it is impossible to understand fully the words spoken by Cleopatra, as if it was the gestures she makes which would allow us to understand the text from the perspective of a person, not her social, political and cultural relationships.

The reciprocal semantic fusion of symbolism is of interest. For example, an ordinary description of the movements of an actress with the sentence "touches the Sphinx's head with her finger" can have a deeply poetic dimension and influence the final meaning of the whole utterance, because 'finger' in Norwid's writings is semantically important. It is enough to recall the following usages of this word: "When the Finger-of-God loomed above me;/Without giving account of worlds it creates," 13 "palec Chrystusowy/Z obłoku wstawa i kreśli widzenie" ("Christ's finger/Rises from a cloud and draws a vision"), (Do Hr. Władysława Zamojskiego, III, 514); "W tym momencie dotknąłem palcem/Zmartwychwstanie I wymówiłem słowo: 'JESTEM' - niespodzianie" ("At this moment I touched the Resurrection with my finger and spoke the word 'I AM'unexpectedly") (Rzecz o wolności słowa, III, 617) or an exquisite metaphor from The Ring of a Grand Lady: "Jakby się j a k i e g o ś tam: OGÓŁU/Dotykało zabłąkanym palcem..." ("As if one touched some WHOLE/With a finger gone astray" (V,196).

In the third scene Cleopatra, in the conversation with a mummy, reveals the reality of her existence, doubt in its sense, she sinks "[...] in the brotherhood of Nothingness", and similarly to the quoted

13 C.K. Norwid, Poems, transl. by Danuta Burchardt, Archipelago Books, New York, 2011, 25. 
fragment, through her negations and affirmation presents her tragic situation. This time, employing the same trick, she does not agree with the existing situation and announces her wishes:

Przyjmując jedzenie

...Syryjskich nie chcę śpiewaków - są miękcy!

Nie chcę rozmów hermejskich - są ciężkie! - Chcę życia:

A mam za towarzysza ciebie!

Do Mumi i

- nicość cichą!

$$
(\mathrm{V}, 25)^{14}
$$

She rejects 'stony', 'Hermeian' reality, although her behaviour is so strongly determined by the surroundings that when she is confronted by it, she gives up. The strong call: "I want life" is annulled in contact with "quiet nothingness". The awareness of her own beauty and attractiveness does not help Cleopatra at all. On the contrary, it seems to deepen her sorrow:

- Któraż z poddanek, licząc osiemnastą wiosnę

I słynną będąc wdzięki swoimi, tak śniada

Jak Kleopatra?... W zamian, oddalone dwory,

Miasta i chaty - baśnie wymyślają o niej,

Dla ucieszenia uszów przypowieściom skłonnych. $(\mathrm{V}, 25)^{15}$

Then, we have an ironic list of all 'love messages', underscored by a bitter ending:

Śmiej się im w parze ze mną! - z niewiastą umarłą,

Która istnego męża nie widziała nigdy,

Lub w błędzie jest, mniemając, że widzialnym byłby!

\footnotetext{
14 “Accepting food//I don't want Syrian singers-they are soft./I don't want Hermeian conversations - they are heavy-I want life./And I have you for my life's companion!//To the Mummy//quiet nothingness."

15 "Which of the serfs, of eighteen years/And being famous for her beauty and swarthy/As Cleopatra?...In return, faraway courts,/Towns and cottages-they invent fairy tales about her./To make glad ears wanting to hear them."
} 
Przestając jedzenie

Miałażbym serce, które sobie uroiło,

Że kochać można wielką miłością na zawsze?

Lub jestże to tytańskim przeciw niebu szałem?

Ideał czuć, co nie był uciosanym w kamień...

$$
(\mathrm{V}, 26)^{16}
$$

It is only here that the reasons for Cleopatra's horrible spiritual state are revealed. She has stopped perceiving herself as a ruler, she has rejected the social role imposed on her, she has noticed a woman in herself, and it turned out that this woman feels an acute deficiency. Her heart in contact with reality hits against the void. Cleopatra has doubts if longings and desires (more specifically a deep conviction about the existence in man of some part of 'I' ready to give and receive love, the kind of love which is "not hewn" by social conventions) are only empty illusion and delusion. "To feel an ideal, which was not hewn in stone" after all this is another objection of Norwid against "women enchanted in dead formulae". This time we see him from a reverse perspective, not of a man, searching in vain for a lively woman, an "enchanted" woman, who suddenly woke up and wants a "true" husband.

Cleopatra's psyche (mentality) was shaped according to the nineteenth century formula. Norwid, in 'the historical tragedy', tells first of all about a man of his generation, crushed not only by fossilized structures and history, but also one who in confrontation with himself (burdened with cultural and historical traces) with an alive personality in himself which primordially was free, goes through the real drama:

\footnotetext{
16 "Laugh at them together with me! - with a dead woman,/who has never seen her real husband,/Or is wrong thinking that he would be visible!//Stops eating//Do I have a heart which imagines,/That one may love with great love forever?/Or is it a titanic madness against heaven?/To feel an ideal, which was not hewn in stone."
} 
Zaprawdę sądom, sędziom podziemnym sterczące

Posyłam za umarłych zadość-uczynienie:

I jasno ci pogląda w czaszkę - o! umarła

Lub umarły... ta, nigdy co nie była żywą.

- Moglibyśmy uścisnąć się, jak znani dawno,

Jak z tejże bez-serdecznej kasty pochodzący,

Choć o tobie podobnież może, jako o mnie,

Niestworzone gadają rzeczy powieściopisarze

I ta która się zowie Historią - ta dobra

Staruszka!... już, co baje, niespełna pamiętna,

Czci-godna, i osobnych dla wieku jej względów.

The protagonist who cannot realize the "the ideal of feelings" which she bears inside, identifies herself with the mummy, but in reality she seems to be in a worse situation, because unlike the mummy, she has never fully lived.

Cleopatra stresses each time she addresses the mummy: "gone [...] dead", referring to the mummy as to man in general, regardless of sex and gender. This is quite important because it allows us to create out of the mummy a symbol, not only of "women enchanted in dead formulae", but simply a man who is spiritually 'mummified' by social etiquette (but also by writers and "History, an old lady"), preserving only the appearance of liveliness and indestructibility. The mummy become a type of a mirror in which everyone can recognize herself. This very bitter diagnosis is true not only about an individual, but of all societies, literally of everything: "znaki są tylko pozorem,/ jak wszystko na tym świecie" ("signs are only appearances,/as everything in the world)" (V, 41) says Her in a conversation with

\footnotetext{
17 "Forsooth, to the courts and to the underground judges,/I send for the dead amends,/And clearly looks into your skull-o the dead one she!/or the dead one he...the one who has never been alive./-We might hug as if we had known each other for long,/As the one coming from this non-sincere caste./Although maybe about you, as about me,/ they say fantastic things, these novelists,/And the one who is called History - this good/Old lady...which invents, not remembering all./Worthy of veneration and separate homage for her age."
} 
the Centurion, while Kondor explains how to keep up appearances through an anecdote with a dry sense of humour:

Skoro się owy weźmie pasztet,

Który ma formę pawia, i skoro się z wnętrza

Formy onej odejmie treść, a kształt zostawi,

Pozór ptaka nie tkniętym może jaśnieć wdziękiem.

$$
(\mathrm{V}, 34)^{18}
$$

Both empires, Egypt and Rome, have been described as stuffed peacocks, and this could be treated as an allusion to the empires of the nineteenth century. The situation of man is to a large extent a consequence of this because "the lot of the nation, its deep, dark soul, which has been reared by necessity hangs over an individual as accomplished stony fate." ${ }^{\prime 9}$

When Cleopatra discovers the illusory character of her life and unknown layers of her personality, she adopts a strategy of waiting; waiting for someone to free her from 'the state of death'. Her expectations are confirmed in the conversation with Szechera:

Szechero! jestem smętna, jak nowo-wyryty

W granicie grób, na kogoś czekający - - Pragnę!

Posuwa kielich, który napełniają podczaszowie

Nie! - tego nie chcę wina - idzie tu przez morze,

Siły nabiera, tracąc natomiast kwiecistość.

Jedną poziomkę, właśnie zerwaną z kroplami

Rosy, przenoszę nad ten ociężały nektar.

18 "If you take this mire,/which has the form of a peacock, and if from the inside/ of this form you subtract the content and preserve the shape,/The appearance of a bird may shine unchanged."

19 Stanisław Brzozowski, Legenda Młodej Polski, quoted in Sławomir Świontek, Norwidowski teatr świata, op. cit., 133 
- Wody pragnę, co granit ma za dno i niebo

Leżące jak w zwierciadle! - lub co pragnę? - nie wiem...

There is something daring in the allusion to Jesus's cry "I thirst" (John, 19:28) on the cross. It creates multiple meanings of each word spoken by Cleopatra. ${ }^{21}$ It refers both to the wine her servants are pouring and to a much deeper thirst. The one going through the sea is a true husband awaited by Cleopatra. On the one hand, this true husband is, of course, Caesar, who by bestowing Cleopatra with love will take her out of the tomb, although the final scenes of the drama suggest that death will come to both protagonists. On the other hand, the metaphor of "the freshly hewn granite tomb" the biblical allusion and the coming one who becomes stronger but "loses in taset", forces us, in a way, to extend the interpretative line to a vision of the coming Jesus and His redemptive sacrifice, and Christianity which comes with him, which will absorb both ancient civilizations.

The deep intuition of the protagonist goes a bit further and covers a bit more than she can understand herself. The desire for crystal clear water and the final "I don't know..." in regards to the object of her desires, strengthen the impressions of ambiguity and the picture of Cleopatra who is only just recognizing herself and trying to codify these recognitions.

Finally, I would like to refer to one more fragment which points to the spiritual path she will take. This fragment presents the holistic experience of Cleopatra in an unusual conclusion:

\footnotetext{
20 "Szechara! I am as sad as a freshly hewn/granite tomb, waiting for someone-I desire!//Pushes a chalice, which is filled by the servants//No! I don't want this wine, it comes here across the sea,/It gains in strength but loses in taste,/One wild strawberry, freshly picked with drops/I transform onto this heavy nectar,/I desire water which has granite for its bottom and sky,/Lying like in a mirror! - or what do I deserve? I don't know..."

21 It seems that this is a peculiar Norwid play on words here. See Jadwiga Puzynina, Słowo Norwida, Wrocław 1990, 13.
} 
[...] Miłość zupełna jest zawsze

Szczesną!...dlatego, że jest!

This confession makes a strong impression. It has the value of a sentence 'heavy' with meaning, is full of difficult optimism, and is condensed to a maximum with the accurately described essence of experience. Love is the highest value, the very feeling itself, and nothing can annul that, it is without conditions, regardless of the end. It has been said in a direct way, strongly, with the highest simplicity and naturalness.

This short sentence of two verses is a clear lyric confession. Here the experience is identical with wore, and identical with the authorial ' 1 '. Where does its convincing power come from? In a way-to use a colloquial expression-the power of this expression has been 'earned' by the whole text, and the context in which the sentence is spoken is also crucial. The authorial emphasis is of course striking. The structure of this sentence is equally important. The introduction of quite a strong enjambment together with the double cadence of the second verse shape the characteristic stringency of the confession. Norwid managed in two short verses to achieve something which-let us call in the 'work in progress' manner-a 'semantic trick'. So, the first verse only states that "love complete is always", therefore it is eternal, constant, even if it has a tragic dimension. The enjambment causes a temporal stop. It is only when a reader reads two verses and understands that at stake here is love-always happy-that s/he will be struck, because s/he will have to connect into one whole the mutually exclusive experiences of tragedy and happiness - not the one which the protagonists have been tasting for a brief moment, but the one which lasts only because love exists.

Norwid was a poet who only rarely resorted to the lyric 'I' in the first person. Despite attempts to hide the protagonist/hero of his poems, he is clearly discernible. The drama by definition

22 "Love complete is always/Happy...Because it is!" 
eliminates the role of a subject organizing the whole of a text, but the situation gets repeated: the overriding persona of the drama could be easily perceived in the lyric structure of the language, in the clear identification with the protagonists, in the unusual intensity of human experience.

The analysed fragments reveal Norwid's art of constructing multi layered meanings. A reader is forced to understand the drama simultaneously on many levels. The personal drama of Cleopatra and Caesar, ergo the drama of the nineteenth-century man, the tragic history of two ancient civilizations and the way the contemporary civilization functions; these are four semantic layers on which Norwid's history-philosophy in this drama is based, ${ }^{23}$ it is the result of the personal, inner experiences of the main protagonists of the drama.

23 While reading Cleopatra and Caesar closely, it is difficult to avoid the impression that we deal here with a polemic dialogue (not intended) with Krasiński's Irydion and the historical and philosophical notions present there. Although structually and chronologically these two texts differ a lot, the polemic voice of Norwid in relations to Krasiński could be seen on at least several levels.

The common platform is inevitability of passing of civilizations and the emphasis of the victory of Christianity. The protagonists of both plays are tragic figures, copying with evil which has come from without. However, Norwid's protagonists are confronted by evil coming from other people and ill structures created by them. Norwid avoid the fact of the existence of metaphysical evil. He seems to be doing it on purpose, because he does not agree with such a strong influence of personal evil upon man's life, as is the case with Masynissa in Irydion. For the same reason he does not deal with a motif of God's providence, which is very important in Krasiński's understanding of history. The ultimate meaning of Irydion is seemingly more optimistic than i Cleopatra and Caesar. Irydion is saved thanks to Kornelia's intervention.

All Norwid's protagonists die. But Irydion, before he is saved, is manipulated by an old man and he destroys others as well as himself. He robs himself of the highest of values: love and humanity. And these are saved Cleopatra and Caesar, despite external pressures and ultimate death. Besides Irydion is exposed to Christianity which he rejects, while, Juliusz, who does not know Christ, with the greatness of his person and his sacrifies, as if anticipates not so much His coming, but His fate on the earthIt seems that this is a peculiar Norwid's play on words here. 
Such a multi directional expression of the understanding of reality is possible thanks to the poetic formation of individual utterances. It seems also that numerous lyric fragments do not allow the philosophical deductions to take over the artistic shape of the drama, especially in those places where dialogues or monologues become too long. Besides, Cleopatra and Caesar seems to be the most obvious example of Norwid's solicitude to preserve the symmetry of the drama, "both to be staged and read". Unfortunately, at times the effect is contradictory to Norwid's intentions, with the loss of balance and the tilts in the direction of reading, rather than staging the drama. Nevertheless, some interesting elements in the structure of the drama can be observed.

What is surprising, on the one hand, is the almost total lack of a plot. The stage is dominated by dialogues, monologues, the focusing of attention on relationships between protagonists, while the elements which could have strengthened tragic motives: the deaths of Pompei and of Caesar, also other events such as battles, the journey of Cleopatra and Julius, and even the royal wedding (the feast is on the stage, the wedding ceremony is off-stage), that is the fragments which should make the drama dynamic, are performed off-stage.

On the other hand, the real plot of the drama (the stressing of the importance of words uttered and the representation of interpersonal relationships-mentioned above) is the result of these off-stage events. Therefore, a conclusion can be drawn that this drama has two tragic levels within it. The first one, which without exaggeration might be called the centre and essence of the tragedy, shows the lot and experiences of Cleopatra. The second, which exists in the scenic space (mostly through evocations), but which happens offstage, is eagerly referred to by researchers as the shaping of "a personal vision of human personality in history". "It is determined by Roman protagonists, and it could summarized in Antonius's words: that: "tacy, jak Julius,- Pompej - albo Marek,/na nic już są" ("such as Julius ,Pompey or Mark/are now for nothing” (V, 154).

24 Sławomir Świontek, Norwidowski teatr świata, op. cit., 137. 
Another interesting device is the construction of the specific movable background to the uttered words. The protagonist speaks while sitting, standing, walking, sometimes eating or dicing. At the same time, on many occasions, in the background we can see the servants busy with their chores, soldiers walking by, the whole army, an approaching ship. As if everything which is dynamic in this drama was subordinated to one goal-to better reception of uttered words and performed gestures, while during the utterances of the main protagonists (Cleopatra, Caesar, the Knight, Szechera) there is no movement backstage in order to focus on what they do and say. This is probably the result of Norwid's concern to recover "the ideas of dramatic silence and ideas of its nature" "pojęcia dramatycznej cis z y i p ojęcia jej natur" (VI, 190). ${ }^{25}$

25 See also: Adela Kuik-Kalinowska, W poszukiwaniu nowego budynku estetyki. Założenia estetyczne a praktyka pisarska, in Eadem, Cypriana Norwida „Czarne kwiaty” i „Białe kwiaty”. Konteksty - poetyka - idee, Słupsk 2002, . 79-123. 